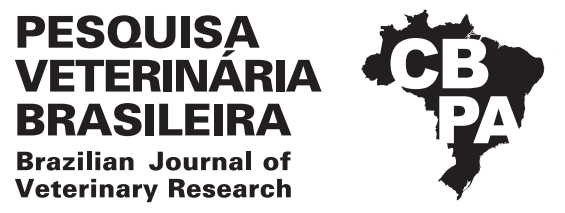

Pesq. Vet. Bras. 39(9):723-727, September 2019 DOI: 10.1590/1678-5150-PVB-6016

Original Article

ISSN 0100-736X (Print)

Livestock Diseases

ISSN 1678-5150 (Online)

\title{
Leukotriene B4 in equine asthma syndrome: what do we know so far? ${ }^{1}$
}

\author{
Juliana N.P. Otaka ${ }^{2 *}$ (D), Luis F.A. Toledo ${ }^{2}$, Katia M. Silva², Andreza A. Silva ${ }^{3}$, \\ Laís Agra ${ }^{4}$, Bruno L. Diaz ${ }^{4}$ and Daniel A.B. Lessa²
}

\begin{abstract}
Otaka J.N.P., Toledo L.F.A., Silva K.M., Silva A.A., Agra L., Diaz B.L. \& Lessa D.A.B. 2019. Leukotriene B4 in equine asthma syndrome: what do we know so far? Pesquisa Veterinária Brasileira 39(9):723-727. Universidade Federal Fluminense, Rua Vital Brazil Filho s/n, Niterói, RJ 24230340, Brazil. E-mail: ju.nabuco@gmail.com

The term "equine asthma syndrome" (EAS) was recently proposed due to the resemblance of the equine disease to human asthma. Leukotrienes cause constriction of the bronchi, especially in the lower airways and increase mucus secretion in the respiratory system. Leukotriene B4 (LTB4) has been discovered as a strong chemotactic factor, which plays a role in neutrophil migration. The immunologic background of EAS remains not fully elucidated despite many studies on the pathogenesis. This study aimed to evaluate the LTB4 concentration in the bronchoalveolar lavage fluid (BALF) of horses with and without pulmonary inflammatory disease. Thirty-five mixed breed horses were studied and LTB4 was determined by using specific ELISA Kit. The horses were grouped by 2 different criteria for statistical analysis of data: 1) according to the values for BALF citology and 2) according to the detection of LTB4 in BALF. There was significant difference of effect of age on the LTB4 detection in equine BALF. Younger animals were the majority where it was possible to detect LTB4 values in LBA. In conclusion, there was an effect of age on the detection of LTB4 in equine BALF, where LTB4 levels were more easily detected in younger animals than older animals and the results of this study raise the possibility of considering future studies with the objective of establishing the real role and the best moment to detect LTB4 in BALF of the equine asthma syndrome.
\end{abstract}

INDEX TERMS: Leukotriene B4, equine, asthma syndrome, BALF, horse, IAD, LTB4, RAO.

RESUMO.- [Leucotrieno B4 na síndrome asmática equina: o que sabemos até o momento?] Recentemente, o termo "síndrome da asma equina" (SAE) foi proposto devido à semelhança da doença equina à asma humana. Os leucotrienos causam constrição dos brônquios, especialmente nas vias aéreas posteriores e aumentam a secreção de muco no sistema respiratório. 0 leucotrieno B4 (LTB4) foi descoberto como um forte fator quimiotático, que desempenha um papel na migração de neutrófilos. 0 fundo imunológico do SAE permanece não completamente elucidado apesar de muitos

\footnotetext{
${ }^{1}$ Received on April 21, 2019.

Accepted for publication on May 7, 2019.

${ }^{2}$ Departamento de Patologia Veterinária e Clínica, Faculdade de Veterinária, Universidade Federal Fluminense (UFF), Rua Vital Brazil Filho s/n, Niterói, RJ 24230340, Brazil. *Corresponding author: ju.nabuco@gmail.com

${ }^{3}$ Departamento de Clínica e Cirurgia, Faculdade de Veterinária, Universidade Federal Rural do Rio de Janeiro (UFRRJ), BR-465 Km 7, Seropédica, RJ 23890-000, Brazil.

${ }^{4}$ Laboratório de Inflamação, Instituto de Biofísica Carlos Chagas, Universidade Federal do Rio de Janeiro (UFRJ), Av. Carlos Chagas Filho 373, CCS, Bloco C, sala C1-024, Ilha do Fundão, Rio de Janeiro, RJ 21941-902, Brazil.
}

estudos sobre a patogênese. Este estudo teve como objetivo avaliar a concentração de LTB4 no lavado broncoalveolar (LBA) de equinos com e sem doença inflamatória pulmonar. Trinta e cinco cavalos de raças mistas foram estudados e o LTB4 foi determinado usando o kit ELISA específico. Os animais foram agrupados por dois critérios diferentes para análise estatística dos dados: 1) de acordo com os valores para citologia do LBA e 2) de acordo com a detecção do LTB4 no LBA. Houve diferença significativa do efeito da idade na detecção do LTB4 no LBA equino. Os animais mais jovens foram a maioria onde foi possível detectar os valores de LTB4 no LBA. Em conclusão, houve um efeito da idade na detecção de LTB4 em LBA equino, onde os níveis de LTB4 foram mais facilmente detectados em animais jovens do que em animais mais velhos e foi possível detectar a concentração de LTB4 no LBA equino e os resultados deste estudo levantam a possibilidade de considerar futuros estudos com o objetivo de estabelecer o real papel e o melhor momento para detectar LTB4 no LBA da síndrome asmática equina.

TERMOS DE INDEXAÇÃO: Leucotrieno B4, síndrome asmática equina, equinos, cavalos, LBA, LTB4. 


\section{INTRODUCTION}

Respiratory tract diseases stands out in equine medicine due to their high prevalence and impact on animal health and economic losses to the equine industry (Michelotto et al. 2013).

According to Barton \& Gehlen (2016), disorders of the respiratory system are the most frequently diagnosed conditions in sport horses evaluated for poor performance, particularly in the lower airways such as equine recurrent airway obstruction (RAO) and inflammatory airway disease (IAD).

Recently, Couëtil et al. (2016) proposed the term "equine asthma syndrome" (EAS) due to the resemblance of the equine disease to human asthma. This term encompasses IAD, classified as mild to moderate asthma, and RAO, classified as severe asthma (Pirie 2017). IAD is a syndrome defined as a nonseptic lower airway condition affecting horses of any age, which usually exhibit subtle clinical signs at rest. The cytological profile of horses with IAD might reveal an increased total nucleated cells count and a very heterogeneous cell population with mild neutrophilia or, alternatively, increased eosinophil counts in equine BALF, while RAO is associated with severe neutrophilic airway inflammation (Richard et al. 2014).

Human asthma has been commonly described as an eosinophilic disease, however it is lately more and more recognized that neutrophilic inflammation may be present in human asthma of all severities as well, but in particular in severe asthmatic patients and during acute disease exacerbation (Nakagome et al. 2012). On the other hand, eosinophils, metachromatic cells, or neutrophils characterize the subforms of mild-to-moderate equine asthma or IAD (Couëtil et al. 2016).

Since the use of fiber-optic endoscopy was first described in horses, cytological and microbiological evaluation of BALF have become the pillars in the diagnosis of respiratory disease alongside clinical and functional examinations (Barton \& Gehlen 2016). Although severely asthmatic horses often show easily visible clinical signs of disease, difficulties may arise in clinical practice due to the fact that patients may be presented in remission. Mild-to-moderate equine asthma tends to occur subclinically as well (Pirie 2017). In these cases, commonly used examination techniques may be insufficient for diagnosis and evaluation of treatment success.

Leukotrienes represent a biologically active group of low molecular weight lipid mediators (i.e., eicosanoids) formed from arachidonic acid. 5-Lipoxygenase (5-LO) is a primary component to this process, initiating the oxidation of arachidonic acid and the subsequent production of intermediate metabolites (e.g., 5-oxe-eicosatetraenoic acid), promoting proinflammatory cell recruitment as well as the eventual formation of the prominent leukotriene subtypes (Ochkur et al. 2013).

Martin et al. (1989) reported that unlike other products of this pathway as leukotrienes C4, D4, and E4, which are potent bronchoconstrictors in humans and animals, the major effects of LTB4 are directed at phagocytes. When studied in vitro, LTB4 promotes chemotaxis of polymorphonuclears (PMN), monocytes, and fibroblasts.

According to Ochkur et al. (2013), the production of leukotrienes is linked with a variety of leukocytes that are both resident and recruited in response to allergen provocation, including neutrophils, eosinophils, mast cells, macrophages, and basophils.

Neutrophils are the most abundant leukocytes in the bloodstream and the first cells to be recruited to a site of inflammation, where primary chemotactic ones are produced, such as formyl-peptides released from bacteria or necrotic cells and complement fragments. Locally, primary chemoattractant gradients recruit more neutrophils into the nucleus of inflammation. After they have reached the site of inflammation, these neutrophils secrete secondary chemoattractants and recruit additional leukocytes, further amplifying the inflammation process. These proinflammatory mediators activate proximal endothelium and increase leukocyte extravasation. It has been proposed that secondary chemoattractants are secreted into sequential waves and LTB4 is the first secondary chemoattractant released at a site of inflammation (Afonso et al. 2012).

LTB4 has been originally discovered as a strong chemotactic factor, which exerts PMN activating abilities and plays a crucial role in neutrophil migration. Several studies have reported elevated levels of LTB4 also in bronchoalveolar lavage (BAL) fluid from human patients with acute respiratory distress syndrome (ARDS). Moreover, the evaluation of LTB4 has been described as useful prognostic indices in human patients with early phase ARDS after admission to the intensive care unit, but there is no data using a horse model of asthma according to the review made by Störmann et al. (2017).

The immunologic background of severe equine asthma remains not fully elucidated despite many studies on the pathogenesis and the therapeutic approach to exacerbation. Therefore, multiple studies have been performed to establish further inflammatory markers for equine respiratory diseases, but there are no data on the role of LTB4 in these diseases yet (Barton \& Gehlen 2016).

Thus, this study aimed to evaluate the LTB4 concentration in the bronchoalveolar lavage fluid (BALF) of horses with and without pulmonary inflammatory disease.

\section{MATERIALS AND METHODS}

Ethical statement. This study was submitted to the Ethics Committee on Animal Experiments of the "Universidade Federal Rural do Rio de Janeiro" (UFRRJ) and approved under the identification number 2927310316. All applicable international, national, and/or institutional guidelines for the care and use of animals were followed.

Animals. Thirty-five mixed breed horses, males and females, with ages from two to 24 years were studied. The horses were raised, extensively, at grass covered pasture (Brachiaria spp. and Andropogon bicornis) without shelter and areas of dry dirt, with minimal exposure to dust, with no exercise training, with supplementary feed consisting of two kilogram per animal of hard commercial feed and mineral salt offered in troughs covered once a day and ad libitum water. The horses were used for practical classes at UFRRJ and were not used for work purposes. The animals were periodically dewormed and vaccinated against tetanus, influenza, rabies, and encephalomyelitis East and West. The horses were clinically evaluated which included evaluation of vital parameters, lung percussion and thoracic auscultation with a re-breathing bag (Jorge et al. 2014). None of the horses showed dyspnea at rest or nasal secretions at the time of the study. Blood and BALF samples were collected during the month of January of 2016 (summer in 
Southern Hemisphere). The animals were grouped by two different criteria for statistical analysis of data:

1) Values for BALF cytology according to Mazan (2010): Healthy Group (HG) - composed by 13 horses which the values for BALF cytology were neutrophils $<5 \%$ and eosinophils $<1 \%$; Sick Group (SG) - composed by 22 horses which the values for BALF cytology were neutrophils $\geq 5 \%$ and/or eosinophils $\geq 1 \%$.

2) Detection of LTB4 in BALF: Leukotriene Group (LKT) - composed by six horses where it was possible to quantify the concentration of this inflammatory mediator; No Leukotriene Group (NoLKT) composed by 29 horses where LTB4 concentration was below the detection limit of the ELISA kit used for this analysis.

Endoscopic examination. A flexible fiberscope was introduced in one of the nostrils and advanced until the tracheal bifurcation (carina) for evaluation of tracheal secretions.

BALF collection. Horses were restrained and sedated with detomidine $1 \%(0.015 \mathrm{mg} / \mathrm{kg})$ associated with butorphanol tartaratec $(0.03 \mathrm{mg} / \mathrm{kg})$ intravenously before the procedure. To anesthetize the airways, including the larynx, tracheal lumen, and the first bronchial segment, $0.5 \%$ lidocaine was instilled by introducing a bronchoalveolar lavage catheter into one of the animal's nostrils until catheter passage resistance was achieved, which signaled that the primary bronchus was reached. After this the catheter's cuff was inflated so that it was stuck to the bronchial segment to infuse the sterile saline solution. BALF was obtained through infusion of two aliquots of $250 \mathrm{~mL}$ of warm physiological isotonic saline solution $\left(37^{\circ} \mathrm{C}\right)$, followed by immediate aspiration of each aliquot. Samples were immediately cooled on ice bath and kept refrigerated until processing within four hours after collection.

Smears for cytology were prepared by cytocentrifugation, followed by fixation with methanol and staining with Giemsa. The slides were examined through an optical microscope with 1000x magnification and the 500-cell count was performed excluding epithelial cells. The cell counts on the slides were made by the same observer.

LTB4 concentration in BALF. The cooled equine BALF samples were centrifuged at $269 \mathrm{xg}$ for $10 \mathrm{~min}$ and the supernatant stored at $-80^{\circ} \mathrm{C}$ until the sample analysis for LTB4 concentrations using the leukotriene B4 ELISA Kit according to manufacturer's instructions (Cayman Chemical ${ }^{\odot}$, Michigan, USA) at the Laboratory of Inflammation of the Institute of Biophysics Carlos Chagas of the "Universidade Federal do Rio de Janeiro".

Statistics. Statistical software IBM ${ }^{\circledR}$ SPSS Statistics 25 was used to perform the Mann-Whitney-U test to identify significant differences $(p<0.05)$ in mean count of Neutrophils, Eosinophils, Macrophages present in equine BALF, age of animals and LTB4 concentration between HG versus SG using and significant differences $(\mathrm{p}<0.05)$ in mean count of neutrophils, eosinophils, macrophages present in equine BALF and age of animals between LKT versus NoLKT groups.

\section{RESULTS AND DISCUSSION}

Of the 35 horses, it was possible to quantify LTB4 in six animals (17.14\%) and of these animals four were sick and two healthy. To our knowledge, this is the first report of detection of LTB4 in equine BALF. The results of the animals analyzed in this study are detailed in the Table 1.

Unexpectedly, there was no significant differences ( $p>0.05)$ between HG and SG neither in mean count of Neutrophils, Eosinophils, Macrophages nor LTB4 concentration in BALF. There was also no effect of age on the occurrence of pulmonary inflammation of horses in this study.
Comparing the groups separated by the LTB4 detection criterion in BALF there was also no significant differences ( $p>0.05)$ between LKT Group and NoLKT Group in mean count of neutrophils, eosinophils and macrophages present in equine BALF, but there was significant difference (U=42.000, $\mathrm{p}<0.05$ ) of effect of age on the LTB4 detection in equine BALF. Younger animals (5/6) were those where it was possible to detect more animals with LTB4 values in BALF than older animals (1/6). This could be explained because young animals are able to respond to immunological challenges, since their leukocytes are present in adequate numbers and are able to respond to antigens satisfactorily, producing the necessary inflammatory mediators (Butcher et al. 2000).

It is worth mentioning that the highest concentration of LTB4 detected was in the two-year-old foal. On the other hand, elderly individuals have higher rates of mortality and morbidity due to infectious diseases. Although the elderly patients have normal numbers of neutrophils in their blood, a decline in their function has been demonstrated through the use of various stimuli. Neutrophils are the leukocytes that respond more rapidly to pathogen invasion, and it is known that there is a decline in their age-related function (immunosenescense) and this may be partly responsible for the greater susceptibility of the elderly to infections (Wenisch et al. 2000). Albeit limited, current evidence suggests that horses likely undergo similar age-related changes in immune function as that observed in people. Immunosenescence includes age-associated remodeling of the immune system resulting in poor immunity and an exaggerated inflammatory state. Although aged horses appear to generally maintain an adequate protective immunity against pathogens, inflammatory diseases are extremely common in the geriatric equid (McFarlane 2016).LTB4 is a potent attractant for inflammatory cells (neutrophils and eosinophils) and these cells have the ability to generate further quantities of LTB4 and other lipoxygenase products (O'Driscoll et al. 1984). It is noteworthy that the only elderly animal in which it was possible to quantify LTB4 concentration was the one that presented the highest percentage of neutrophils (26.2\%), that is, it presented more than $20 \%$ of neutrophils, which characterizes it as a severe case of equine asthma (Couëtil et al. 2016). It is necessary to emphasize that Animal 2 also presented a BALF cytology compatible with EAS (10.4\% of neutrophils), however the percentage was less than half of the Animal 4 and both horses had similar concentrations of LTB4 which corroborates with that described by Wenisch et al. 2000 and McFarlane 2016.

In later 2017, Störmann et al. evaluated the concentration of LTB4 in polytraumatic pigs and verified significant levels of LTB4 in BALF up to 72 hours after trauma, demonstrating the flashing action of this inflammatory mediator. Therefore, LTB4 could be used as an early marker of inflammatory processes in the respiratory system. Chronic diseases have lower odds of detecting LTB4 in BALF when compared to acute diseases or cases of inflammatory condition exacerbation. Afonso et al. (2012) described leukotriene B4 (LTB4) as the first secondary chemoattractant released at an inflammation site, confirming its rapid action. In agreement with this finding, Antonelli et al. (1994) suggest that LTB4 levels have been shown to correlate with the number of neutrophils recovered from the BAL fluid of human patients with ARDS. Additionally, Ochkur et al. (2013) report that another leukotriene, other 
Table 1. Identification, age, mean percentage of BALF cytology (neutrophils, lymphocytes, macrophages and eosinophils), cytological classification and LTB4 concentration in BALF of horses included in this study

\begin{tabular}{|c|c|c|c|c|c|c|c|c|}
\hline \multicolumn{3}{|c|}{ Animal } & \multirow{2}{*}{$\begin{array}{c}\begin{array}{c}\text { Age } \\
\text { (Years) }\end{array} \\
2\end{array}$} & \multirow{2}{*}{$\begin{array}{c}\text { Neutrophils } \\
(\%)\end{array}$} & \multirow{2}{*}{$\begin{array}{c}\text { Linphocytes } \\
(\%)\end{array}$} & \multirow{2}{*}{$\begin{array}{c}\text { Macrophages } \\
(\%)\end{array}$} & \multirow{2}{*}{$\begin{array}{c}\begin{array}{c}\text { Eosinophils } \\
(\%)\end{array} \\
0.2\end{array}$} & \multirow{2}{*}{$\begin{array}{c}\begin{array}{c}\text { LTB4 } \\
(\mathrm{pg} / \mathrm{mL})\end{array} \\
8.803 .022\end{array}$} \\
\hline SG & LKT & 1 & & & & & & \\
\hline & & 2 & 3 & 10.4 & 50 & 37.4 & 2.2 & 3.520 .752 \\
\hline & & 3 & 3 & 9.5 & 27 & 62.7 & 0.8 & 2.487 .726 \\
\hline & & 4 & 18 & 26.2 & 30 & 37.4 & 6.4 & 3.897 .825 \\
\hline & NoLKT & 5 & 3 & 8 & 44 & 47.2 & 0.8 & ND \\
\hline & & 6 & 5 & 5.4 & 53 & 40.2 & 1.4 & ND \\
\hline & & 7 & 2 & 4 & 56.6 & 37.8 & 1.4 & ND \\
\hline & & 8 & 7 & 14.4 & 42 & 43.6 & 0 & ND \\
\hline & & 9 & 9 & 5 & 57.6 & 37.4 & 0 & ND \\
\hline & & 10 & 14 & 12.3 & 48 & 39.7 & 0 & ND \\
\hline & & 11 & 10 & 14.4 & 51 & 38.2 & 0 & ND \\
\hline & & 12 & 9 & 6.6 & 52.8 & 40 & 0.6 & ND \\
\hline & & 13 & 13 & 5.4 & 59.2 & 35.2 & 0.2 & ND \\
\hline & & 14 & 14 & 7.8 & 68 & 23.2 & 1 & ND \\
\hline & & 15 & 16 & 7.6 & 51.6 & 33 & 7.8 & ND \\
\hline & & 16 & 16 & 11.8 & 29 & 59.2 & 0 & ND \\
\hline & & 17 & 16 & 10 & 49.6 & 40.2 & 0.2 & ND \\
\hline & & 18 & 19 & 12 & 42 & 36.8 & 0.2 & ND \\
\hline & & 19 & 19 & 12.8 & 37.4 & 49.6 & 0.2 & ND \\
\hline & & 20 & 3 & 5.6 & 55.6 & 38.8 & 0 & ND \\
\hline & & 21 & 24 & 14 & 45.7 & 40.3 & 0 & ND \\
\hline & & 22 & 13 & 5.4 & 56.4 & 37.8 & 0.4 & ND \\
\hline \multirow[t]{13}{*}{$\mathrm{HG}$} & LKT & 23 & 3 & 3 & 54.4 & 42.4 & 0 & 0.8591229 \\
\hline & & 24 & 5 & 3.2 & 58 & 38.8 & 0 & 1.136 .526 \\
\hline & NoLKT & 25 & 4 & 4.8 & 50.6 & 44.6 & 0 & ND \\
\hline & & 26 & 6 & 2.8 & 67.6 & 29.4 & 0.2 & ND \\
\hline & & 27 & 8 & 3.6 & 60.4 & 35.8 & 0.2 & ND \\
\hline & & 28 & 8 & 3.6 & 52.2 & 44.2 & 0 & ND \\
\hline & & 29 & 12 & 1.4 & 43.2 & 49 & 0.4 & ND \\
\hline & & 30 & 9 & 3 & 48.2 & 48 & 0.4 & ND \\
\hline & & 31 & 9 & 3.6 & 36.6 & 59 & 0.8 & ND \\
\hline & & 32 & 17 & 4.8 & 41.3 & 53.9 & 0 & ND \\
\hline & & 33 & 17 & 3.2 & 63.2 & 33.2 & 0.4 & ND \\
\hline & & 34 & 3 & 2.6 & 36.4 & 61 & 0 & ND \\
\hline & & 35 & 3 & 4.4 & 48.4 & 46.8 & 0 & ND \\
\hline
\end{tabular}

$\overline{\mathrm{SG}}=$ sick group, $\mathrm{HG}=$ healthy group, $\mathrm{LKT}=$ possible to quantify the concentration of LTB4, NoLKT = not possible to quantify the concentration of LTB4.

than LTB4, plays an important role in pulmonary remodeling in chronic respiratory processes and its study in mice reveals that the progressive pulmonary fibrosis appears to occur as a consequence of leukotriene-mediated activities. In particular, this chronic inflammatory metric was shown to be a function of cys-leukotrienes, and not LTB4. It could explain why our experiment were not able to detect LTB4 in all horses with BALF cytology compatible with lower respiratory tract inflammation, because it is believed that animals with inflammatory BALF cytology compatible with pulmonary inflammatory disease are in a chronic or remission condition situations where LTB4 would no longer be the chemotactic protagonist.

Another factor contributing to the non-detection of LTB4 is that although the ELISA has the economic advantage, it also has its limitations. The use of the ELISA has bottlenecks: ELISA technique certainly has its specificity limitations due to used detection antibodies, corroborating with what has already been described by Störmann et al. (2017) when they recommend, for future studies, that samples should be analyzed by liquid chromatography-ultraviolet-tandem mass spectrometry technique, since is more reliable and sensitive method to quantity LTB4.

\section{CONCLUSION}

In conclusion, it was possible to detect the concentration of LTB4 in the equine LBA. It was also concluded that there was an effect of age on the detection of LTB4 in equine BAL, where LTB4 levels were more easily detected in younger animals than older animals. The results of this study raise the possibility of considering future studies with the objective of establishing the real role and the best moment to detect LTB4 in BALF of the equine asthma syndrome. 
Acknowledgments.- Special thanks to the "Universidade Federal do Rio de Janeiro" group for their help in the dosages of LTB4 and also to all "Universidade Federal Rural do Rio de Janeiro" group for helping us in the BALF collection of this study.

Conflict of interest.- The authors declared no potential conflicts of interest with respect to the research, authorship, and/or publication of this article.

\section{REFERENCES}

Afonso P.V., Janka-Junttila M., Lee Y.J., McCann C.P., Oliver C.M., Aamer K.A., Losert W., Cicerone M.T. \& Parent C.A. 2012. LTB4 Is a signal-relay molecule during neutrophil chemotaxis. Dev. Cell 22(5):1079-1091.<http://dx.doi. org/10.1016/j.devcel.2012.02.003><PMid:22542839>

Antonelli M., Raponi G., Lenti L., Severi L., Capelli O., Riccioni L., De Blasi R.A., Conti G. \& Mancini C. 1994. Leukotrienes and alpha tumor necrosis factor levels in the bronchoalveolar lavage fluid of patient at risk for the adult respiratory distress syndrome. Minerva Anestesiol. 60(9):419-426. <PMid:7808646>

Barton A.K. \& Gehlen H. 2016. Pulmonary remodeling in equine asthma: what do we know about mediators of inflammation in the horse? Mediators of Inflamm. 2016:1-11. <http://dx.doi.org/10.1155/2016/5693205> <PMid:28053371>

Butcher S., Chahel H. \& Lord J.M. 2000. Ageing and the neutrophil: no appetite for killing? Immunology 100(4):411-416. <http://dx.doi. org/10.1046/j.1365-2567.2000.00079.x><PMid:10929066>

Couëtil L.L., Cardwell J.M., Gerber V., Lavoie J.P., Léguillette R. \& Richard E.A. 2016. Inflammatory airway disease of horses-revised consensus statement. J. Vet. Intern. Med. 30(2):503-515. <http://dx.doi.org/10.1111/ jvim.13824><PMid:26806374>

Jorge M.L.L.A., Viscardi V., Silva K.M., Otaka J.N.P., Alencar N.X., Torres Filho R.A. \& Lessa D.A.B. 2014. Atividade da fosfatase alcalina no lavado broncoalveolar de equinos de policiamento montado no Estado do Rio de Janeiro. Ciência Rural 44(1):92-96. <http://dx.doi.org/10.1590/S010384782014000100015>

Martin T.R., Pistorese B.P., Chi E.Y., Goodman R.B. \& Matthay M.A. 1989. Effects of leukotriene B4 in the human lung. Recruitment of neutrophils into the alveolar spaces without a change in protein permeability. J. Clin. Invest. 84(5):1609-1619.<http://dx.doi.org/10.1172/JCI114338><PMid:2553777>
Mazan M.R. 2010. Inflammatory airway disease in the horse. Focus Meeting: focus on upper and lower respiratory diseases, American Association of Equine Practitioners, Salt Lake City, UT, p.100-106.

McFarlane D. 2016. Immune dysfunction in aged horses. Vet. Clin. N. Am., Equine Pract. 32(2):333-341. <http://dx.doi.org/10.1016/j.cveq.2016.04.009> <PMid:27329495>

Michelotto P.V., Lessa D.A.B., Silva K.M., Gawlowski K.R.S. \& Fernandes W.R. 2013. The airway fluid analysis: methods and interpretation for the athletic horse. Revta Bras. Ciênc. Vet. 20(1):1-5.

Nakagome K., Matsushita S. \& Nagata M. 2012. Neutrophilic inflammation in severe asthma. Int. Arch. Allergy Immunol. 158(Suppl.1):96-102. <http:// dx.doi.org/10.1159/000337801><PMid:22627375>

O’Driscoll B.R., Cromwell O. \& Kay A.B. 1984. Sputum leukotrienes in obstructive airways diseases. J. Clin. Exp. Immunol. 55(2):397-404. <PMid:6321071>

Ochkur S.I., Protheroe C.A., Li W., Colbert D.C., Zellner K.R., Shen H.H., Luster A.D., Irvin C.G., Lee J.J. \& Lee N.A. 2013. Cys-leukotrienes promote fibrosis in a mouse model of eosinophil-mediated respiratory inflammation. Am. J. Respir. Cell Mol. Biol. 49(6):107-1084. <http://dx.doi.org/10.1165/ rcmb.2013-00090C> <PMid:23859654>

Pirie R.S. 2017. Mild to moderate equine asthma: an overview. Livestock 22(3):158-163. <http://dx.doi.org/10.12968/live.2017.22.3.158>

Richard E.A., Depecker M., Defontis M., Leleu C., Fortier G., Pitel P.H. \& Couroucé-Malblanc A. 2014. Cytokine concentrations in bronchoalveolar lavage fluid from horses with neutrophilic inflammatory airway disease. J. Vet. Intern. Med. 28(6):1838-1844. <http://dx.doi.org/10.1111/ jvim.12464><PMid:25269933>

Störmann P., Auner B., Schimunek L., Serve R., Horst K., Simon T.P., Pfeifer R., Köhler K., Hildebrand F., Wutzler S., Pape H.C., Marzi I. \& Relja B. 2017. Leukotriene B4 indicates lung injury and on-going inflammatory changes after severe trauma in a porcine long-term model. Prostaglandins Leukot. Essent. Fatty Acids 127:25-31. <http://dx.doi.org/10.1016/j. plefa.2017.09.014><PMid:29156155>

Wenisch C., Patruta S., Daxböck F., Krause R. \& Hörl W. 2000. Effect of age on human neutrophil function. J. Leukoc. Biol. 67(1):40-45. <http://dx.doi. org/10.1002/jlb.67.1.40> <PMid:10647996> 